\title{
RISIKO MOSQUITO-BORNE DISEASES PADA WISATAWAN DI INDONESIA DAN PERAN TRAVEL HEALTH NURSING
}

\author{
Putu Ayu Asri Damayanti ${ }^{1}$, Ni Luh Putu Eva Yanti \\ ${ }^{1}$ Departemen Parasitologi, \\ ${ }^{2}$ Departemen Keperawatan, Divisi Keperawatan Jiwa dan Komunitas \\ Fakultas Kedokteran, Universitas Udayana \\ Alamat korespondensi: asri_damayanti@unud.ac.id
}

\begin{abstract}
Abstrak
Kunjungan wisatawan internasional meningkat setiap tahun mencapai 1,4 milyar wisatawan pada tahun 2019. Peningkatan kunjungan wisatawan akan meningkatkan risiko wisatawan untuk mengalami gangguan kesehatan. Ganguan kesehatan yang banyak ditemui wisatawan bersumber dari penyakit yang ditularkan melalui gigitan nyamuk yang dikenal dengan mosquito-borne diseases (MBD). Indonesia sebagai salah satu tujuan wisata endemis terhadap MBD seperti malaria, Dengue, Chikungunya, Japanese Encephalitis (JE), dan limfatik filariasis. Wisatawan harus mempersiapkan diri sebelum melakukan perjalanan dan mencari informasi tentang tempat yang dikunjungi. Perawat travel health melakukan pelayanan sebelum perjalanan (pre-travel), setelah perjalanan (post-travel), dan saat wisata (during/in-transit care) dengan berfokus pada pencegahan primer dan sekunder pada penyakit yang berhubungan dengan perjalanan wisata. Pencegahan terhadap gigitan nyamuk dan kemoprofilakss adalah upaya pencegahan yang efektif karena sebagian besar MBD belum ada obat dan vaksinnya kecuali penyakit JE. Profesi perawat travel health sangat dibutuhkan untuk menyiapkan dan memantau kesehatan para wisatawan.
\end{abstract}

Kata kunci: mosquito-borne diseases, perawat, travel health, wisatawan

\begin{abstract}
International tourist arrivals increase every year, reaching 1.4 billion tourists in 2019 . The increase in tourist visits will increase the risk of tourists experiencing health problems. Health problems for tourists generally originate from diseases transmitted through mosquito bites, known as mosquito-borne diseases (MBD). Malaria, dengue, chikungunya, Japanese encephalitis (JE) and lymphatic filariasis are endemic diseases in Indonesia. Tourists must prepare themselves before traveling to Indonesia and looking for information about the places visited. Travel health nurses carry out travel health services before travel (pre-travel), after travel (post-travel), and during travel (during / in-transit care) by focusing on primary and secondary prevention of diseases related to travel. Prevention of mosquito bites and chemoprophylaxes is an effective preventive measure because most MBD does not vaccine preventable diseases except for JE. The travel health nursing is needed to prepare and monitor the health of tourists.
\end{abstract}

Keyword: mosquito-borne diseases, nurse, travel health, tourist

\section{PENDAHULUAN}

Kunjungan wisatawan internasional pada tahun 2019 meningkat 5\% dari tahun 2018 mencapai 1.4 milyar. Daerah Eropa masih merupakaan tujuan wisata yang paling digemari yaitu mencapai 710 juta lalu disusul Asia Pasifik (348 juta), Amerika (216 juta), Afrika (67 juta), dan Timur Tengah (60 juta). Angka ini diperkirakan akan bertambah mencapai 1,8 milyar di tahun 2030 (UNWTO, 2019). Jumlah kunjungan 
wisatawan internasional ke Indonesia pada tahun 2019 mencapai 16.11 juta kunjungan, naik sebesar 1,88\% dari tahun 2018 yang berjumlah 15,81 kunjungan. Berdasarkan asal negara wisatawan yang berkunjung ke Indonesia pada tahun 2019 berasal dari Malaysia (2,98 juta), Tiongkok (2,07 juta), Singapura (1,93 juta), Australia (1.39 juta) dan Timor Leste (1,18 ribu) (Badan Pusat Statistik, 2020).

Alasan melakukan perjalanan (travel) dan karakteristik wisatawan manca negara ataupun domestik cukup bervariasi. Alasan mengadakan perjalanan pada umumnya adalah berlibur untuk mencari kesenangan (leisure). Alasan lainnya adalah untuk bisnis, mencari pengobatan, menempuh pelatihan/studi singkat, pekerjaan di bidang kemanusiaan, dan mengunjungi kerabat atau teman. Karakteristik wisatawan juga bervariasi dari wisatawan tunggal, berkelompok, usia lanjut, keluarga dengan anak kecil, wanita hamil, dan wisatawan dengan penyakit penyerta. Apapun tinjuan dan karakteristik wisatawan maka harus dilakukan persiapan dan perencanaan yang matang sebelumnya (pre-travel) agar perjalanan menjadi lancar. Perencanaan pretravel meliputi penilaian rencana perjalanan, menentukan potensi bahaya kesehatan, edukasi pada wisatawan, menyiapkan tindak pencegahan (vaksinasi atau kemoprofilaksis), dan mempersiapkan wisatawan agar mampu mengelola kesehatan mereka selama perjalanan. Wisatawan juga dituntut untuk memiliki pengetahuan yang cukup tentang risiko kesehatan yang akan ditemui di daerah tujuan, geografisnya, aspek antropologis masyarakatnya, dan regulasi kesehatan di daerah tujuan (Patel and Simons, 2019).

Peningkatan jumlah wisatawan diiringi dengan semakin banyaknya wisatawan yang mengalami gangguan kesehatan. Penyakit infeksi pada wisatawan semakin meningkat jumlahnya seiring makin meningkatnya kunjungan wisatawan ke negara berkembang. Sebuah studi yang dilakukan Angelo, et al.(2017) menyatakan bahwa sebesar 6\%$87 \%$ wisatawan tanpa memandang tempat tujuan wisata, mengalami penyakit infeksi saat berwisata maupun setelah kembali ke negara asal. Wisatawan yang berkunjung ke negera berkembang sebanyak 43\%-79\% menjadi sakit. Dalam studi tersebut dikatakan tempat tujuan wisata mayoritas adalah Asia dan Afrika dengan rerata tinggal 8-21 hari (Angelo et al., 2017).

Data International Association for Medical Assistance to Traveller (IAMAT) untuk Indonesia menyatakan ada beberapa jenis penyakit infeksi yang harus diwaspadai oleh wisatawan luar negeri ataupun wisatawan domestik jika berkunjung ke Indonesia. Penyakit yang ditularkan dengan bantuan vektor nyamuk mosquito-borne-diseases (MBD) adalah salah satu kelompok penyakit yang masih endemis di Indonesia yaitu Malaria, Chikungunya, Dengue, Zika, dan limfatik filariasis (IAMAT, 2020a).

\section{MOSQUITO-BORNE DISEASES (MBD)}

MBD adalah kumpulan penyakit yang ditularkan melalui gigitan nyamuk. Nyamuk merupakan vektor kompeten dalam menularkan berbagai mikroorganisme penyebab penyakit. Indonesia adalah daerah tropis yang merupakan habitat yang ideal untuk nyamuk. Terdapat 4 genus nyamuk yang umum menularkan penyakit yaitu genus Aedes, Culex, Anopheles, dan Mansonia (Tabel 1). Program pengendalian vektor menemui banyak kendala seperti adanya resistensi nyamuk terhadap insektisida, kurangnya partisipasi masyarakat dalam melakukan program pemberantasan sarang nyamuk, dan belum adanya vaksinasi yang efektif (Mnzava et al., 2015). Hal ini 
menyebabkan kasus penyakit MBD sangat sulit untuk dikendalikan terutama pada awal dan akhir musim hujan.

\section{Malaria}

Malaria adalah penyakit infeksi protozoa Plasmodium sp. yang ditularkan melalui gigitan nyamuk Anopheles betina. Penyakit ini dapat ditemukan di beberapa wilayah Indonesia. Data Kemenkes tahun 2019 mencatat DKI Jakarta, Bali, dan Jawa Timur telah dinyatakan bebas malaria sedangkan 11 provinsi lainnya yaitu Sumatera Utara, Sumatera Barat, Sulawesi Tenggara, Lampung, Kepulauan Riau, Maluku Utara, Kalimantan Timur, Maluku, Nusa Tenggara Timur, Papua Barat, dan Papua masih berstatus endemis sedang dan tinggi. Tiga provinsi terakhir yaitu Papua Barat, Papua, dan NTT memiliki kasus malaria terbanyak. Jumlah total kasus malaria tahun 2019 yaitu 250.644 kasus positif malaria (KEMENKES RI, 2020)

Berdasarkan malaria chat risk yang dikeluarkan oleh IAMAT, risiko malaria di Indonesia berada di ketinggian di bawah 2.000 meter; penularan terjadi sepanjang tahun; vektor utama adalah An. balabacensis dan An. sundaicus; insiden P. falciparum malaria mencapai 57\%; dilaporkannya $P$. falciparum yang mengalami resistensi terhadap berbagai jenis obat (multi drug resisten) di seluruh daerah Indonesia; dan $P$. vivax yang resisten terhadap klorokuin (IAMAT, 2020a). Nyamuk Anopheles yang merupakan vektor malaria adalah nyamuk nokturnal yaitu nyamuk yang beraktifitas aktif di malam hari.

Seiring makin tingginya kunjungan wisatawan ke daerah endemis malaria maka terjadi peningkatan kasus malaria impor di negara Eropa, Amerika, Inggris, dan Australia (WHO, 2016a). Terdapat 6.5007.500 kasus malaria per tahun di Eropa sejak tahun 2011 (ECDCC, 2019). Sebanyak 64 kasus malaria dilaporkan pada 118 juta wisatawan yang mengunjungi kawasan Asia Tenggara dengan relative risk sebesar 11.5 (8.3-15.9) di tahun 2004. Wisatawan yang berisiko terkena malaria adalah wisatawan yang tidak melakukan kemoprofilaksis, melakukan perjalanan ke daerah pedalaman, berlayar antar pulau, atau melakukan kegiatan pada malam hari. Dilihat dari alasan perjalanan maka wisatawan yang bepergian untuk mengunjungi teman dan keluarga yang memiliki risiko lebih tinggi terkena malaria yaitu sebanyak $80 \%$ kasus malaria. Berwisata ke Asia berpeluang dua kali lebih tinggi terkena malaria. Pada umumnya wisatawan terinfeksi Plasmodium falciparum atau $P$.vivax, sedangkan $P$. ovale dan $P$. malariae sebagai penyebab malaria hanya berkisar $<5 \%$ (Lalloo and Magill, 2019)

Wisatawan yang melakukan kemoprofilaksis dapat melindungi wisatawan dari komplikasi fatal malaria. Wisatawan dan dokter diinformasikan untuk selalu waspada terhadap gejala demam dan flu yang timbul dalam waktu 7 hari sampai beberapa bulan setelah meninggalkan daerah yang endemis malaria. Diagnosis yang dini sangat menentukan keberhasilan terapi. Terdapat beberapa obat pilihan yaitu AtavaquoneProguanil, Doxycycline, atau Mefloquine hydrochloride. WHO menyatakan tidak ada satupun obat kemoprofilaksis efektif 100\% sehingga harus dikombinasi pencegahan gigitan nyamuk (WHO, 2015).

\section{Dengue}

Indonesia adalah daerah endemis penyakit Dengue. Penyakit Dengue disebabkan oleh infeksi virus Dengue yang ditularkan oleh nyamuk Aedes aegypti dan Ae. albopictus. Selain Indonesia, wisatawan yang berkunjung ke Amerika tengah, Amerika Selatan, Afrika, Asia, dan Oseania juga berisiko tertular Dengue (Wilder-Smith, 
2012). Insiden DBD sejumlah 51,48 per 100.000 penduduk dengan rerata mortalitas $0,67 \%$. Lima provinsi tertinggi insiden Dengue adalah Kalimantan Utara, Kalimantan Timur, Bali, Gorontalo, dan Maluku Utara (KEMENKES RI, 2020). Gejala timbul 4-7 hari setelah tergigit nyamuk Aedes betina yang mengandung virus dengan gejala demam, nyeri di belakang mata, sakit kepala, kemerahan, peteki, nyeri tulang sendi, dan dapat menjadi Demam Berdarah Dengue (DBD) dengan tanda pendarahan di berbagai organ vital, syok, bahkan kematian. Sampai saat ini belum ada obat dan vaksin yang efektif. Pasien yang terkena reinfeksi dengan serotipe virus yang sama akan menjadi imun, namun jika terinfeksi serotipe virus yang berbeda maka akan berpotensi menjadi DBD(WHO, 2020a).

\section{Chikungunya}

Chikungunya adalah salah satu penyakit yang ditularkan melalui perantara nyamuk yaitu nyamuk Aedes. Seluruh wilayah Indonesia pernah melaporkan kasus Chikungunya. Jumlah kasus penyakit ini pada tahun 2019 adalah 5.042 kasus. Gejala penyakit yang ringan menyebabkan banyak penderita yang tidak mencari pengobatan sehingga tidak terdata. Penyakit ini disebabkan oleh infeksi virus Chikungunya, virus RNA yang masuk ke dalam famili Togaviridae. Gejala Chikungunya bervariasi dari tidak bergejala sampai timbul gejala 2-12 hari setelah tergigit nyamuk Aedes aegypti dan Ae.albopictus yang terinfeksi. Gejala berupa demam, nyeri otot dan sendi yang parah. Terkadang dapat disertai dengan sakit kepala, mual, muntah, dan kemerahan. Pada umumnya dapat sembuh sempurna namun beberapa penderita masih mengalami nyeri sendi yang dapat berlangsung kronis dan mengalami komplikasi pada mata, saluran cerna, saraf, dan jantung. Belum ada vaksin maupun obat antiviral untuk penyakit ini, penanganan bersifat suportif. Wisatawan diminta untuk melindungi diri dari gigitan nyamuk Aedes di sepanjang hari dari pagi hingga sore. Selain Indonesia, wisatawan yang berkunjung ke Kepulauan Karibia, Amerika Tengah, Amerika Selatan, SubSahara Afrika, Asia Tenggara, dan Subbenua India juga berisiko terhadap Chikungunya (WHO, 2020b).

\section{Japanese Encephalitis (JE)}

Seluruh wilayah Indonesia yang berdaerah tropis berisiko terhadap penyakit JE terutama anak di bawah 15 tahun. Kasus JE di Bali memiliki insiden 7,1 per 100.000 anak pada tahun 2003 dan dilaporkan 43 kasus JE pada tahun 216 di Manado. Kasus JE pada wisatawan yang diteliti sejak tahun 19732008 berjumlah 55 kasus dari 17 negara, termasuk wisatawan yang sebelumnya berkunjung ke Bali tercatat sebanyak 10 kasus. Wisatawan tersebut berasal dari berbagai negara yaitu Australia, Swedia, Denmark, Perancis, Belanda, dan Jerman (Kari et al., 2006; Hills et al., 2010; Garjito et al., 2018). Wisatawan yang hendak bepergian ke daerah endemis JE harus melakukan vaksinasi JE terutama wisatawan dengan anak-anak dan orang tua karena belum ada terapi definitif untuk JE (Erlanger et al., 2009). Bali pada tahun 2018 telah melakukan program vaksinasi JE (Im et al., 2018). Pencegahan lain yang dapat dilakukan oleh wisatawan adalah selalu melindungi diri dari gigitan nyamuk.

Penyakit JE disebabkan oleh virus RNA genus Flavivirus yang ditularkan melaui gigitan nyamuk genus Culex saat malam hari. Penyakit JE merupakan salah satu penyakit zoonosis yaitu ditularkan dari binatang sumber virus ke manusia melalui gigitan nyamuk. Binatang yang merupakan sumber virus (amplifying host) adalah babi dan burung air. Berdasarkan habitat babi, burung air dan nyamuk maka wisatawan yang tinggal 
lama atau beraktifitas daerah pedalaman, peternakan, kandang babi, sawah, dan area irigasi adalah berisiko tinggi tertular (Adi et al., 2016; Damayanti et al., 2017; Lindahl et al., 2012).

Pada umumnya penyakit ini tidak bergejala. Anak di bawah 15 tahun atau orang tua rentan terinfeksi JE. Dengan masa inkubasi 5-15 hari setelah virus masuk melalui gigitan nyamuk. Gejala umumnya demam, sakit kepala, muntah, diare, lemas, dan gejala neurologis berupa kejang, tremor, kelumpuhan baik ekteremitas maupun kelumpuhan sistem pernafasan, retensi urin, dan gangguan perilaku. Gejala bisa menjadi fatal pada $20-30 \%$ kasus dan sering menimbulkan gejala sisa seperti gangguan neurologis, kelainan psikiatri dan permasalahan kognitif (Kari et al., 2006).

\section{Zika}

Belum terdapat bukti adanya wabah Zika di Indonesia. IAMAT menyatakan adanya kemungkinan keterbatasan deteksi dan Zika umumnya tidak bergejala sehingga kasus Zika tidak terlaporkan di Indonesia. Hanya ada satu kasus Zika yang terpublikasi di Indonesia pada tahun 2016 (Perkasa et al., 2016). Penyakit Zika adalah penyakit yang disebabkan oleh infeksi virus Zika yang ditularkan melalui gigitan nyamuk Aedes aegypti dan Aedes albopictus. Virus Zika dapat ditularkan secara horizontal dari satu penderita ke penderita lain melalui hubungan seksual dan vertikal dari ibu ke janin yang dikandung. Janin yang terinfeksi bisa menderita mikrosefali (Kuna and Gajewski, 2016) (WHO, 2016b) Virus Zika dapat bertahan pada cairan semen pria sampai 188 hari (Nicastri et al., 2016). Wisatawan yang sedang hamil dilarang untuk bepergian ke daerah endemis Zika. Wisatawan yang berkunjung ke Asia Tenggara, Amerika Latin, Oceania, dan Afrika juga berisiko terinfeksi Zika. Wisatawan juga dapat melakukan tindakan perlindungan dari gigitan nyamuk, menunda perjalanan pada wanita hamil, melakukan hubungan seksual dengan perlindungan, dan tidak merencanakan kehamilan selama 3-6 bulan setelah perjalanan (Kuna and Gajewski, 2016).

Zika pada umumnya tidak bergejala. Zika sering salah didiagnosis dengan Dengue dan Chikungunya. Gejala sangat bervariasi berupa demam, sakit kepala, nyeri tulang dan sendi, mual, muntah, lemas, mata kemerahan, kemerahan pada seluruh tubuh, diare, nyeri perut, pusing, dan sensitif terhadap cahaya. Pada janin yang terinfeksi dapat mengalami mikrosefali dan gangguan neurologis (Barzon et al., 2016). Zika juga dikaitkan dengan komplikasi Guillain-Barre Syndrome yaitu penyakit autoimun yang ditandai dengan kelumpuhan akut (Broutet et al., 2016). Sampai saat ini belum ada pengobatan dan vaksin untuk Zika.

\section{Limfatik Filariasis}

Kasus limfatik filariasis di Indonesia pada tahun 2018 mencapai 10.681 kasus yang menyebar di seluruh provinsi di Indoenesia. Pada data Geosentinel ditemukan 271 kasus $(0.62 \%)$ wisatawan menderita filariasis dengan 25\% diantaranya disebabkan oleh filaria Wuchereria bancrofti (Lipner et al., 2007) WHO mengupayakan agar penyakit filariasis dapat dieleminasi pada tahun 2020 di seluruh dunia.

Filariasis atau yang dikenal dengan penyakit kaki gajah di Indonesia adalah penyakit menahun yang disebabkan oleh cacing filaria yang ditularkan melalui gigitan nyamuk. Cacing filaria yang terdapat di Indoenesia adalah Wuchereria bancrofti, Brugia malayi, dan Brugia timori. Cacing filaria ini dapat menyumbat saluran dan kelenjar limfa sehingga dapat mengakibatkan pembengkakan menetap pada ekstremitas, 
alat genital, dan payudara. Penularan penyakit ini melalui gigitan nyamuk genus Culex, Aedes, Anopheles, dan Mansonia yang mengandung cacing filaria stadium Larva 3 (L3) infektif. Saat nyamuk menghisap darah, ketika nyamuk menarik probosisnya maka saat itulah L3 masuk ke dalam tubuh. Cacing filaria dalam tubuh dapat bertahan selama 57 tahun yang menyebabkan penderita menjadi sumber penularan selama kurun waktu tersebut. Untuk nenurunkan kasus penularan maka seluruh penduduk melakukan pecegahan masal dengan meminum obat Diethylcarbamazine (DEC) dan Albendazole setiap setahun sekali (KEMENKES RI, 2020). Begitu pula bagi wisatawan yang berkunjung ke daerah endemis juga harus meminum obat pencegahan.

Tabel 1. Vektor, perilaku nyamuk dan penyakit yang ditularkan

\begin{tabular}{lll}
\hline Vektor (genus) & Karaterisk perilaku nyamuk & Penyakit \\
\hline Anopheles & Aktif malam hari & Malaria \\
& Di dalam dan di luar ruangan & Limfatik filariasis \\
& Pedesaan/pedalaman (rural) & \\
\hline Aedes & Aktif dari fajar sampai senja & Dengue \\
& Umumnya di luar ruangan & Chikungunya \\
& Daerah urban & Limfatik filariasis \\
\hline Culex & Menggigit malam hari & Japanese encephalitis \\
& Umumnya di luar ruangan & Limfatik filariasis \\
& Pedesaan dan urban & Chikungunya \\
\hline Mansonia & Aktif malam hari & Chikungunya \\
& & Limfatik filariasis \\
\hline
\end{tabular}

\section{PERAWAT TRAVEL HEALTH}

Meningkatnya gangguan kesehatan yang dialami oleh wisatawan menyebabkan para wisatawan harus mempersiapkan diri sebelum perjalanan dan mampu mengelola kesehatannya selama berwisata. Salah satu profesi yang berperan dalam menjaga kesahatan wisatawan adalah perawat travel health (travel health nursing). Perawat di bidang travel health menurut American Travel health Nurses Association (ATHNA) dan Royal College Nursing (RCN) bertugas untuk melakukan pelayanan kepada wisatawan sebelum perjalanan (pre-travel), setelah perjalanan (post-travel), dan perawatan saat transit (in-transit care) dengan berfokus pada pencegahan primer dan sekunder pada penyakit yang berhubungan dengan perjalanan wisata (ATHNA, 2019; RCN, 2019).

\section{Penilaian Risiko Sebelum Perjalanan (Pre-} travel risk assessment)

Perawat travel health harus melakukan penilaian risiko sebelum perjalanan (pretravel risk assessment). Penilaian risiko pretravel adalah berisi proses pengumpulan informasi berhubungan dengan wisatawan dan perjalanan (itinerary) yang akan dilakukan (Tabel2.). Informasi wisatawan yang perlu digali adalah umur, jenis kelamin, riwayat medis (lampau dan terkini, termasuk riwayat keluarga), keterbatasan (disability), status kesehatan mental, kebutuhan khusus lainnya, pengobatan, riwayat alergi, data vaksinasi, pengalaman wisata sebelumnya, dan pengetahuan wisatawan tentang risiko kesehatan yang mungkin dihadapi di tempat tujuan. Khusus untuk wanita perlu juga diketahui status kehamilan, menyusui, rencana kehamilan, dan kontrasepsi. Informasi tentang perjalanan yang harus dinilai adalah destinasi, waktu 
keberangkatan, lama tinggal, moda transportasi, tujuan perjalanan, rencana aktifitas, kualitas akomodasi, keuangan, standar kesehatan di tempat tujuan, dan asuransi kesehatan (RCN, 2019).

Informasi wisatawan sehubungan dengan penyakit MBD harus digali secara tertulis melalui pengisian formulir yang kemudian dilanjutkan dengan bertemu untuk melakukan konsultasi. Banyak sekali informasi yang harus digali dari wisatawan. Informasi tentang usia dan jenis kelamin yaitu anak-anak dan wanita hamil sangat berguna karena mereka sangat berisiko jika terkena penyakit MBD yang masih endemis di negara tujuan. WHO melaporkan mortalitas malaria falciparum tertinggi terjadi pada anak dan wanita hamil. Selain itu yang perlu diperhatikan adalah terdapat kontraindikasi terhadap beberapa jenis obat profilaksis malaria pada anak, wanita hamil, dan menyusui seperti pada obat doxycycline. Anak-anak dan orang tua juga harus mendapat vaksinasi JE sebelum berwisata karena termasuk penyakit vaccine preventable. Endemisitas daerah tujuan terhadap Dengue juga harus diperhatikan bagi anak yang masih balita karena rentan dengan akibat kebocoran plasma yang terjadi pada penyakit dengue yang berat (DBD). Status imunitas wisatawan lanjut usia yang rendah dan sering disertai dengan penyakit penyerta dapat menempatkan mereka dalam kondisi berbahaya jika terinfeksi penyakit MBD. Penyakit Zika sangat berbahaya pada wanita hamil karena menimbulkan mikrosefali pada janinnya dan pasangan yang sedang merencanakan kehamilan karena virus lama bertahan pada cairan semen. Informasi mengenai riwayat kesehatan juga harus diperhatikan seperti jika memiliki riwayat operasi pengangkatan limpa, epilepsi, kelainan ginjal, dan hati maka sebaiknya tidak bepergian ke wilayah endemis malaria. Hal ini berhubungan dengan limpa adalah organ penting dalam pertahanan infeksi malaria, serta kemoprofilaksis dalam jangka waktu lama memerlukan kondisi ginjal dan hati yang prima. Kondisi epilepsi juga membatasi pilihan kemoprofilaksis malaria. Penderita yang memiliki riwayat penyakit HIV harus mendapat perhatian lebih karena jika imunitas menurun akan mudah mengalami gejala penyakit yang parah dan pemberian vaksin aktif akan sangat berisiko. Riwayat alergi juga sangat perlu diketahui misalkan saja ada riwayat alergi terhadap gigitan serangga, alergi terhadap obat kemoprofilaksis atau obat lainnya. Riwyat alergi, vaksinasi, dan pengobatan perlu didokumentasikan dan dibawa olah wisatawan ke tempat tujuan (RCN, 2019).

Tabel2. Informasi pada kuesioner penilaian risiko pre-travel (Lalloo and Magill, 2019)

\begin{tabular}{ll}
\hline Topik & Rincian \\
\hline Tempat yang dikunjungi & Negara, Kota \\
Keberangkatan & Tanggal dan waktu keberangkatan \\
Lama tinggal & Total lama tinggal dan masa tinggal di tiap lokas \\
Tujuan wisata & Berlibur, bisnis, medis, mengunjugi kerabat/teman, olah raga, dan \\
& alasan lain \\
Tipe akomodasi & Mewah, sedang, fasilitas minimal/kemah \\
Umur & Bayi, anak, dewasa, usia lanjut \\
Riwayat vaksinasi & Vaksinasi perjalanan, vaksinasi rutin, riwayat efek samping (vaso- \\
& vagal) \\
Kondisi kesehatan terkini & Penyakit yang sedang diderita, imunitas \\
Riwayat kesehatan & Riwayat penyakit, operasi, kondisi medis penting \\
Kondisi kesehatan mental & Depresi, cemas, percobaan bunuh diri \\
Pengobatan & Daftar obat yang dikonsumsi rutin \\
Riwayat alergi & Obat, makanan, bahan lain \\
\hline
\end{tabular}


Informasi tentang perjalanan wisatawan juga harus dinilai. Perawat harus telah memiliki informasi tentang jenis penyakit MBD yang sedang endemis di daerah destinasi dan menilai seberapa jauh pengetahuan wisatawan terhadap hal tersebut. Lama tinggal dan jenis aktifitas yang dilakukan perlu juga diketahui. Aktifitas di luar ruangan, daerah tujuan yang terpencil, akomodasi yang buruk, dan tinggal dalam jangka waktu yang lama akan berpotensi mendapat gigitan nyamuk yang mengandung virus MBD. Adapun saran yang harus diinfokan kepada wisatawan untuk mencegah gigitan nyamuk berupa penggunaan penolak nyamuk (repellent) spray atau losion yang diaplikasikan ke kulit sesuai dengan instruksi yang tertera pada kemasan, repellent mengandung salah satu bahan DEET, Picaridin (Icaridin), IR3535, minyak lemon eucalyptus (OLE) atau para-menthane-diol (PMD) 2-undecanone. Jika menggunakan pelindung matahari maka repellent harus diaplikasikan setelahnya. Menggunakan pakaian yang berwarna terang, menutupi tubuh, dan dapat menggunakan pakaian yang telah mengandung permethrin. Wisatawan juga dipastikan menggunakan pendingin ruangan, kawat kasa yang telah menutupi semua ventilasi atau menggunakan kelambu yang berinsektisida di tempat menginap (IAMAT, 2020b).

\section{Penilaian Risiko Setelah Perjalanan (Post- travel assessment)}

Wisatawan yang kembali dari perjalanan juga harus dilakukan pelayanan travel health. Menurut ATHNA perawat travel health harus kompeten dalam melakukan pelayanan post travel yang berupa skrining baik pada wisatawan yang tidak bergejala maupun yang sedang sakit, dan melakukan kajian pada wisatawan dengan demam, diare, gangguan saluran pernafasan, gangguan kulit dan jaringan lunak (ATHNA, 2019).

Diawali dengan menggali data dasar melalui kuesioner untuk melihat risiko tertular penyakit MBD seperti data destinasi, lama tinggal, riwayat profilaksis malaria (kemoprofilaksis ataupun tindakan pencegahan gigitan nyamuk), kegiatan yang dilakukan selama wisata, kegiatan di alam terbuka, riwayat sakit saat wisata. Setelah mendapat data dasar maka dilakukan skrining umum dan khusus. Skrining umum berupa tes laboratorium darah dan urin, ultrasound abdomen, dan elektrokardiografi. Untuk kasus MBD dapat melakukan pemeriksaan laboratorium darah untuk mencari adanya tanda infeksi, eosinofilia sebagai tanda infeksi filariasis, dan sering ditemukan perpanjangan Q-T pada EKG wisatawan yang mendapat pengobatan antimalarial halofantrine. Skrining khusus juga perlu dilakukan untuk mencari adanya infeksi tersembunyi karena sedang dalam masa inkubasi ataupun tidak bergejala karena imunitas yang dimiliki. Pada penyakit MBD malaria perlu dilakukan pemeriksaan hapusan darah tebal maupun tes serologis (antigen atau antibodi) mengingat malaria memiliki masa inkubasi 10 hari - 1 tahun dan bisa kambuh dalam waktu 2-10 tahun jika plasmodium masih ada di dalam tubuh. Pemeriksaan skrining filariasis dapat berupa pemeriksaan serologis (antigen antibodi) serta mikrofilaremia nokturnal (pemeriksaan darah saat malam hari mengingat mikrofilaria aktif di malam hari). Pemeriksaan serologik Dengue, JE, dan Zika juga diperlukan jika daerah tujuan endemis terhadap penyakit tersebut (Clerinx et al., 2019) 
Kegiatan post-travel selain skrining, perawat travel health juga melakukan kajian pada wisatawan yang memiliki gejala penyakit demam, diare, gangguan saluran pernafasan, gangguan kulit dan jaringan lunak. Di antara semua gejala tersebut, demam merupakan gejala yang paling sering ditemukan pada penderita penyakit MBD. Demam juga merupakan gejala utama wisatawan dirawat di rumah sakit dimana sebesar 20-30\% wisatawan yang demam disebabkan karena menderita malaria falciparum (Boggild and Liles, 2017). Dengue juga merupakan penyebab demam yang sering mengenai wisatawan yang kembali yaitu berkisar $2 \%$ $6 \%$ dimana mayoritas wisatawan tersebut kembali dari daerah wisata di Asia Tenggara (51\%) (Boggild and Liles, 2017). Di sentra atau fasilitas kesehatan dengan kerja sama antar profesi akan dilakukan pemeriksaan untuk mencari diagnosis dan terapi yang tepat bagi wisatawan yang mengalami demam. Biasanya pemeriksaan yang dilakukan adalah pemeriksaan darah lengkap (perhatikan hitung platelet), enzim dan fungsi hati, kultur darah, tes malaria dan Dengue, serta pemeriksaan $x$-ray dada (Clerinx et al., 2019).

Perawatan saat berwisata (during travel atau in transit care)

ATHNA menyatakan perawat travel health juga melakukan pelayanan pada wisatawan saat sedang berwisata. Perawat dapat melakukan konseling menggunakan telehealth (email atau panggilan jarak jauh) jika wisatawan masih di tempat wisata atau konseling langsung jika ada wisatawan yang memerlukan di wilayahnya. Perawat juga dapat memberi referensi rujukan untuk mendapatkan obat yang dibutuhkan, merawat efek samping obat, bantuan untuk evakuasi, dan dapat memberi pelayanan kesehatan dalam perjalanan wisata kelompok. Dalam hal memberi pelayanan kesehatan tersebut, perawat dapat memberi rekomendasi perlengkapan medis yang dibutuhkan, perubahan kebijakan dan prosedur perjalanan (ATHNA, 2019).

\section{KESIMPULAN}

Penyakit malaria, Dengue, Chikungunya, Japanese Encephalitis (JE), dan limfatik filariasis adalah penyakit MBD yang masih endemis di Indonesia dan dapat mengancam kesehatan para wisatawan yang berkunjung. Dengan bantuan perawat travel health dalam melakukan persiapan pre travel, menangani gangguan kesehatan selama berwisata, dan melakukan skrining dan perawatan post travel maka gangguan kesehatan pada wisatawan dapat dicegah dan dikelola dengan baik.

Angelo, K.M., Kozarsky, P.E., Ryan, E.T., Chen, L.H., Sotir, M.J., 2017. What proportion of international travellers acquire a travel-related illness? A review of the literature. J. Travel Med. 24, 1-8. doi:10.1093/jtm/tax046

ATHNA, 2019. Travel Health Nursing Fact Sheet [WWW Document]. Am. Travel Heal. Nurses Assoc. URL 
https://www.athna.org/about/factSheet. asp

Badan Pusat Statistik, 2020. Perkembangan Pariwisata dan Transportasi Nasional Desember 2019. Ber. Resmi Stat. 13, $1-16$.

Barzon, L., Trevisan, M., Sinigaglia, A., Lavezzo, E., Palù, G., 2016. Zika virus: From pathogenesis to disease control. FEMS Microbiol. Lett. 363, 1-17. doi:10.1093/femsle/fnw202

Boggild, A.K., Liles, W.C., 2017. TravelAcquired Illnesses Associated with Fever, in: The Travel and Tropical Medicine Manual. pp. 271-299. doi:10.1016/c2010-0-66958-6

Broutet, N., Krauer, F., Riesen, M., Khalakdina, A., Almiron, M., Aldighieri, S., Espinal, M., Low, N., Dye, C., 2016. Zika virus as a cause of neurologic disorders. N. Engl. J. Med. 374, 1506-1509. doi:10.1056/NEJMp1602708

Clerinx, J., Hamer, D., Libman, M., 2019. Posttravel, in: Keystone, J.S., Kozarsky, P.E., Connor, B.A., Mendelson, M. (Eds.), Tarvel Medicine. Elsevier, pp. 487-494.

Damayanti, P.A.A., Adi, A.A.A.M., Astawa, I.N.M., Sudarmaja, I.M., Kardena, I.M., Swastika, I.K., 2017. Incidence of Japanese Encephalitis among Children is associated with the Presence of Pigs in Bali , Indonesia. Biomed. Pharmacol. J. 10, 1333-1338.

ECDCC, 2019. Annual Epidemiological Report for 2016 Malaria. Stockholm.

Erlanger, T.E., Weiss, S., Keiser, J., Utzinger, J., Wiedenmayer, K., 2009. Past, present, and future of Japanese encephalitis. Emerg. Infect. Dis. 15, 17. doi:10.3201/eid1501.080311

Garjito, T.A., Widiarti, Anggraeni, Y.M., Alfiah, S., Satoto, T.B.T., Farchanny, A., Samaan, G., Afelt, A., Manguin, S., Frutos, R., Aditama, T.Y., 2018.
Japanese Encephalitis in Indonesia: An Update on Epidemiology and

Transmission Ecology. Acta Trop. 187, 240-247.

doi:10.1016/j.actatropica.2018.08.017

Hills, S.L., Griggs, A.C., Fischer, M., 2010. Japanese encephalitis in travelers from non-endemic countries, 1973-2008.

Am. J. Trop. Med. Hyg. 82, 930-936. doi:10.4269/ajtmh.2010.09-0676

IAMAT, 2020a. World Malaria Risk Chart [WWW Document]. Int. Assoc. Med. Assist. to Travel. URL https:/www.iamat.org/world-malariarisk-chart

IAMAT, 2020b. Insect bite prevention [WWW Document]. Int. Assoc. Med. Assist. to Travel. URL https://www.canada.ca/en/publichealth/services/diseases/insect-biteprevention.html

Im, J., Balasubramanian, R., Yastini, N.W., Suwarba, I.G.N., Andayani, A.R., Bura, V., Jeon, H.J., Clemens, J.D., Marks, F., 2018. Protecting children against Japanese encephalitis in Bali, Indonesia. Lancet 391, 2500-2501. doi:10.1016/S0140-6736(18)31191-7

Kari, K., Liu, W., Gautama, K., Junior, M.P.M., Clemens, J.D., Nisalak, A., Subrata, K., Kim, H.K., Xu, Z., 2006. A hospital-based surveillance for Japanese encephalitis in Bali , Indonesia. BMC Med. 7, 2-8. doi:10.1186/1741-7015-4-8

KEMENKES RI, 2020. Profil Kesehatan Indonesia Tahun 2019, Kementrian Kesehatan Repoblik Indonesia.

Kuna, A., Gajewski, M., 2016. Prevention of sexual transmission of Zika virus. Int. Marit. Health 67, 179-180. doi:10.5603/IMH.2016.0033

Lalloo, D.G., Magill, A.J., 2019. Malaria, in: Keystone, J.S., Kozarsky, P.E., Freedman, D.O., Nothdurft, H.D., Connor, B.A. (Eds.), Travel Medicine. 
Mosby Elsevier, Philadelphia, pp. 137144.

Lindahl, J., Chirico, J., Boqvist, S., Thu,

H.T.V., Magnusson, U., 2012.

Occurrence of Japanese encephalitis

virus mosquito vectors in relation to

urban pig holdings. Am. J. Trop. Med.

Hyg. 87, 1076-1082.

doi:10.4269/ajtmh.2012.12-0315

Lipner, E.M., Law, M.A., Barnett, E., Keystone, J.S., von Sonnenburg, F., Loutan, L., Prevots, D.R., Klion, A.D., Nutman, T.B., Brown, G., Torresi, J., Carosi, G., Castelli, F., Chen, L., Connor, B., Delmont, J., Parola, P., Franco, C., Kozarsky, P., Freedman, D., Gelman, S., Hall, D., Guruman, A., Haulman, J., Jong, E., Kain, K., Licitra, C., Pandey, P., Schlagenhauf, P., Steffen, R., Schwartz, E., Shaw, M., Wilson, M., Wittner, M., Einstein, A., 2007. Filariasis in travelers presenting to the GeoSentinel Surveillance Network. PLoS Negl. Trop. Dis. 1, 1-7. doi:10.1371/journal.pntd.0000088

Mnzava, A.P., Knox, T.B., Temu, E.A., Trett, A., Fornadel, C., Hemingway, J., 2015. Implementation of the global plan for insecticide resistance management in malaria vectors : progress, challenges and the way forward. Malar. J. 1-9. doi:10.1186/s12936-015-0693-4

Nicastri, E., Castilletti, C., Liuzzi, G., Iannetta, M., Capobianchi, M.R., Ippolito, G., 2016. Persistent detection of Zika virus RNA in semen for six months after symptom onset in a traveller returning from Haiti to Italy, February 2016. Eurosurveillance. doi:10.2807/1560-

7917.ES.2016.21.32.30314

Patel, D., Simons, H., 2019. Travel Health. Public Health 168, 148-149.

0
Perkasa, A., Yudhaputri, F., Haryanto, S., Hayati, R.F., Ma'Roef, C.N., Antonjaya, U., Yohan, B., Myint, K.S.A., Ledermann, J.P., Rosenberg, R., Powers, A.M., Sasmono, R.T., 2016. Isolation of zika virus from febrile patient, Indonesia. Emerg. Infect. Dis. 22, 924-925. doi:10.3201/eid2205.151915

RCN, 2019. Competencies: Travel health nursing: career and competence development. doi:10.13140/RG.2.2.15273.24165

UNWTO, 2019. International Tourism Highlights, International Tourism Highlights. World Tourism Organization, Madrid.

WHO, 2020a. Dengue and severe dengue [WWW Document]. WHO. URL http://www.who.int/mediacentre/factsh eets/fs117/en/

WHO, 2020b. Chikungunya [WWW Document]. World Heal. Organ. URL http://www.who.int/mediacentre/factsh eets/fs327/en/

WHO, 2016a. World Malaria Report 2016. Geneva.

WHO, 2016b. Screening, assessment and management of neonates and infants with complications associated with Zika virus exposure in utero: Rapid Advice Guideline, World Health Organization. Geneva.

WHO, 2015. Guidelines for The Treatment of Malaria [WWW Document]. World Heal. Organ. URL https://www.who.int/docs/defaultsource/documents/publications/gmp/gui delines-for-the-treatment-of-malariaeng.pdf?sfvrsn $=a 0138 b 77 \_2$

Wilder-Smith, A., 2012. Dengue infections in travellers. Paediatr. Int. Child Health $32,28-32$.

doi:10.1179/2046904712Z.0000000005 